\title{
Research Paper: An Approach to the Anthropological Theory of the Qur'an and Hadith and Their Roles in Reducing Environmental Degradation
}

Hossein Masoumbeigi ${ }^{1}$ Q, Narjes Malek Mohammadi², Hossein Shamsi Gooshki ${ }^{3}$, Abolfazl Khoshi $^{3,4}$, Mehdi Mesri $^{3}$, Fathollah Najjarzadegan ${ }^{2}$, Ali $^{2}$ Esrafili $^{5,6}$, Majid Kermani ${ }^{5,6}$, Norouz Mahmoudi ${ }^{1,5,6^{*}} \mathrm{Q}$

1. Health Research Center, Life Style Institute, Baqiyatallah University of Medical Sciences, Tehran, Iran.

2. Department of Hadith and Qur'anic Sciences, Faculty of Theology, Campus of Qom, University of Tehran, Qom, Iran.

3. Medicine, Research Center Quran and Hadith, Baqiyatallah University of Medical Sciences, Tehran, Iran.

4. Department of Medical Ethics, Faculty of Medicine, Baqiyatallah University of Medical Sciences, Tehran, Iran.

5. Research Center of Environmental Health Technology, Iran University of Medical Sciences, Tehran, Iran.

6. Department of Environmental Health Engineering, School of Public Health, Iran University of Medical Sciences, Tehran, Iran.

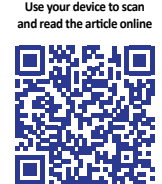

Citation Masoumbeigi H, Malek Mohammadi N, Shamsi Gooshki H, Khoshi A, Mesri M, Najjarzadegan F, et al. An Approach to the Anthropological Theory of the Qur'an and Hadith and Their Roles in Reducing Environmental Degradation. International Journal of Medical Toxicology and Forensic Medicine. 2021; 11(4):36166. https://doi.org/10.32598/ijmtfm.v11i4.36166

https://doi.org/10.32598/ijmtfm.v11i4.36166

(4) 03

Article info:

Received: 18 Sep 2021

First Revision: 22 Oct 2021

Accepted: 29 Oct 2021

Published: 21 Dec 2021

\section{Keywords:}

Qur'an, Anthropology,

Environmental ethics,

Environmental protection,

Environmental degradation

\section{ABSTRACT}

Background: According to the Qur'an, man is the servant and the successor of Allah, the representative of prosperity on earth, and has the responsibility for the universe. This approach will create a constructive human interaction with the environment. Environmental degradation is against the will of Allah. It originates from ignorance, human selfishness, passions, and evil temptations, manifest in greed, arrogance, and extravagance. If humans control these abnormal factors and follow Qur'an teachings, they will enjoy a healthy environment that is a universal right. This paper seeks to study the anthropological theory of the Qur'an and its role in reducing environmental degradation.

Methods: Based on the descriptive-analytical design, we explored 70 verses of the Holy Qur'an in which the words samā', 'ard, mas'ūl, khalīfah, shaytān, and those are cognate with the Arabic verbs sa-khkhara, ha-ra-sa, sa-ra-fa, ki-ba-ra, ha-wā, 'a-ba-da, and 'a-ma-ra, as well as the related articles, books, and philological and exegetical sources. We investigated the Qur'an to find the effect of awareness and more attention of human beings to the dimensions of man's creation to reduce environmental degradation. These issues will be discussed in two parts: 1) the anthropology and the dimensions of human creation in the Qur'an, and 2) the causes of environmental degradation.

Results: This study showed that the survival of life and human enjoyment of a healthy environment depends on enough knowledge of oneself, seeking help from Allah, and following the Qur'anic guidelines. These facts effectively control internal and external causes of environmental degradation, including ignorance, egoism, selfishness, and evil temptations. These actions destroy the roots of greed, arrogance, and extravagance in human beings. For this reason, Allah demands humans to develop earth, care for and rescue it from any destruction, avoid extravagance, and observe justice.

Conclusion: Meditating in the Qur'an, the man knows his creative dimensions and environmental degradation factors that are incompatible with nature and are rooted in some of the inner and outer dimensions of human personality. Hence, he will consciously enjoy sustainable development and maintaining a healthy environment. This behavior will then reduce anomalies in the environment on his part.

\footnotetext{
* Corresponding Author:

Norouz Mahmoudi, PhD candidate.

Address: Health Research Center, Life style Institute, Baqiyatallah University of Medical Sciences, Tehran, Iran.

Tel: +98 (912) 8097429
}

E-mail:m.n.noroz@gmail.com 


\section{Introduction}

$\mathbf{T}$

he economic, social, and cultural development must be sustainable, with the least environmental damage and impact on human health and the environment. So control, monitoring, and observance of health principles are essential to achieve a healthy society [1].

The Holy Qur'an, as the essential book of guidance in human life, pays special attention to the preservation of the environment. It warns man of environmental destruction and encourages the development and proper use of nature and divine blessings (Hūd: 61). The Qur'an guides man to the generous natural world to enjoy the existence of divine blessings and be a pioneer in development, kindness, and goodness. Allah says: "On the earth are signs for those of assured faith" (Zārīyāt: 20), "...Glory to Him who has subjected these to our (use), for we could never be able to do it" (Zukhruf: 13).

The environment encompasses all external conditions affecting the life and development of an organism. This definition includes the air, water, and land and the interrelationship between them and all living creatures [2]. The environment is Allah's creation. Its protection and preservation, which is a sign and verse from the greatness of Allah, is obligatory. If a man thinks that the only reason for protecting the environment is to benefit from it, this belief may lead to its misuse or destruction [3]. According to Article 50 of the Constitution of the Islamic Republic of Iran, preserving the environment is a public duty because the present and future generations have a right to flourish in this environment. Economic and other activities that inevitably involve degradation of the environment or cause irreparable damage to it are therefore forbidden [4].

Environmental degradation means having bad attitudes and behaviors in taking advantage of this divine gift, which leads to water, soil, air, noise, landscape pollution, and so on. Awareness of environmental issues has increased dramatically in recent decades. The general public believes that the consumption of products and the use of various services will significantly impact the resources and quality of the environment. These effects can occur at all stages of a product's life, from the extraction of raw materials to its production, distribution, consumption, and waste management [5]. Although the sources of pollution in many countries of the world are industries, this is not an excuse for us as the planet's inhabitants to help this cycle by producing waste and ignoring the non-recyclable waste that we leave in nature.
We should not help the industries in further polluting the earth. Today, waste disposal and overproduction, lack of proper management, and their return to the reuse cycle lead to environmental pollution, loss of natural resources, and environmental degradation. Therefore, proper management of waste production and recycling is one of the most important ways to reduce environmental degradation [6].

Also, the entry of pollutants and heavy and toxic metals such as mercury, lead, cadmium, etc., into the environment into the water, soil [7-9], and air [10] endanger the health of all members of society [11-13].

Therefore, the most effective step for environmental protection is evaluating people's behavior and performance in achieving the basic principles of sustainable living. People should evaluate their interactions with the environment and observe standard norms and principles of coexistence with nature. The correct use of resources and preventing the waste of natural gifts cause stability and durability of life [14]. This issue can also be considered from a legal perspective. Allah created nature and the environment for all human beings and gave them the right to possess and use them. This right exists for all men at all times [15].

As Allah says, "It is Allah who has subjected the sea to you, that ships may sail through it by His command, that you may seek of His bounty, and that you may be grateful. And He has subjected to you, as from Him, all that is in the heavens and on earth, behold, in that are signs indeed for those who reflect" (Jāthīyah: 12-13).

Therefore, moral and correct use of the environment must always take place to meet the needs and respect the rights of others. The environment is the bedrock of human social life. If the right to life is considered the first fundamental human right, the right to have a healthy environment in which a sustainable environment is provided for people precedes the right to life in some aspects, and it is necessary to hand this right and other human rights, in different aspects. Accordingly, environmental protection is the protection of social life [16].

\section{Materials and Methods}

This research is a review study of the descriptiveanalytical type. We reviewed 70 verses of the Holy Qur'an in which the words samā', 'ard, mas' ūl, khalīfah, shaytān, and the Arabic verbs of sa-khkha-ra, ha-ra-sa, sa-ra-fa, ki-ba-ra, ha-wā, 'a-ba-da, and 'a-ma-ra, and the related articles, books, and philological and exegetical 
sources. This research answers the questions of "Is the promotion of awareness and more attention of people to the dimensions of their creation through the Qur'an is effective in reducing environmental degradation?" and "If a man knows this Qur'anic view, will it lead to control the destructive factors of the environment in society?"

It is necessary to control high-risk behaviors in the environment and seriously deal with them that endanger human life with various threats. Many strict laws and regulations have been enacted worldwide to curb environmental misconduct. As the evidence and events show the recurrence of environmental damages by humans, the question that arises here is that why laws and regulations alone have not been enough to protect the environment. On the other hand, the proper use of the environment requires eliminating the causes of environmental degradation in human beings. In the following, these issues will be discussed in two parts: 1) the anthropology and the dimensions of human creation in the Qur'an, and 2) the roots of environmental degradation.

\section{Results and Discussion}

\subsection{Dimensions of human creation in Qur'an}

According to Qur'an, man has unique and valuable creative dimensions such as successor, builder, responsible, and Allah servant. Allah gave him the right to enjoy the divine blessings and gifts in nature. So he is entrusted to essential tasks like environmental protection. It requires, on the one hand, human awareness of the mentioned dimensions and, on the other hand, fulfillment of his duties, especially in preventing the destruction of nature and the environment.

\subsubsection{Man is the Caliph of Allah on earth}

Islam gives a prominent position to man. According to some Qur'an verses (Baqarah: 30; Fātir: 39; Yūnus: 14), man is called a "Caliph", meaning "successor" of Allah on earth. According to some others (Baqarah: 29; A'rāf: 10), Allah has provided many possibilities for men in nature to play this role. He established a close harmony and connection between the evolution of man and other beings so that man could meet his needs. As a result, he must take care of the land entrusted to him, for he has to be finally responsible before Allah on how he monitored the resources of this planet and used them. Intellect (aql) is a unique capacity available to man and distinguishes him from other creatures [17].
Imam Sadeq (AS) says: "Allah Almighty says: I swear by my honor and glory that I did not create a creature more beloved than intellect, and I gave it only to those whom I love completely. He also says: My order, forbiddance, reward, and punishment belong only for humans" [18]. Therefore, a person who enjoys the most beloved divine blessing, namely intellect and authority, has a heavy duty and should be careful not to use this authority against Allah's will because all environmental factors that affect human health, his quality and lifestyle, are part of his authority. By gaining the necessary awareness and correcting his attitude, a wise man should show worthy behavior deserved the dignity of the best creature, i.e., a man who is the lover and protector of environmental health. Islam and the Qur'an expect such behavior from the faithful and righteous servants of Allah.

In addition, the Almighty Allah, who has given manpower and superiority, has constantly warned people not to deviate from the straight path in order not to be regrettable and harmful: "Verily, this is my way, leading straight, follow it, follow not (other) paths, they will scatter you about from His path" ('An'ām: 153). Therefore, in Islamic thought, Allah has stated the direction of the flourishing of these talents and has shown the way to man [19].

So everything is for the man who is the caliph of Allah and is prostrated by angels. He possesses perfection, as the Qur'an says: "For those who believe and work righteous deeds, there will be gardens of bliss" (Luqmān: 8). Man minus faith is deficient and imperfect. Such a person may be greedy, bloodthirsty, and stingy, so he is an infidel and even inferior to the animal [20]. He can have traits such as greed, avarice, etc., and then becomes the servant of Satan, submitting his will to Satan and hurrying to hell, the lowest dignity, and the painful divine punishment. $\mathrm{He}$ will take actions such as destroying the environment.

Therefore, man, who is the caliph of Allah on earth, has essential duties that, according to the Qur'anic verses such as Luqmān: 19, 'A'rāf: 10, and Baqarah: 152, while using the environment in a balanced way, should be thankful for the infinite divine blessing. One of the practical ways to thank Allah for the blessings is to protect the environment.

\subsubsection{Man is the developer of the earth}

Man is the developer and is responsible for the administration and construction of the earth. This nature, with all its benefits and facilities, has been entrusted to him. The Qur'an states this concept clearly: “...He who had created you from the earth and settled you therein..." (Hood: 61). 
Based on this verse, there are several opinions about the development and construction of the earth as follows:

A) After learning the religious teachings, the most crucial element of the divine caliphate is building and developing the earth and saving it from destruction, devastation, and darkness. Earth refers to the extent of human life. Therefore, ethics and environmental culture are integral parts of Allah's successor on earth. Whoever pollutes the air instead of purifying it, destroys the earth instead of building it, cuts trees instead of planting, and pollutes seas and deserts instead of sanitizing them, he indeed pollutes the glorious title of a caliphate.

The word "wasta'marakum" in this verse provides a stable environment that deserves human status and guides him towards perfection. It then will save the earth from the danger of destruction and moral damage. Then the human body will enjoy the benefits of natural medicine and the soul from the special gifts of the merciful soul [21].

B) According to a report of Nu'mānī's commentary under this verse, Imam Ali (AS) says: "What is said in the Qur'an about the livelihood and life of people and their causes, Allah Almighty has explained to us five aspects: development, building, trade, rent, and alms". Imam pays special attention to the development of the earth because he considers it a means of providing sustenance and the continuation of human life. Therefore, to continue on earth, the earth must be built and developed [22].

C) The Qur'an does not say: "Allah developed the earth and gave it to you", instead, it says: "Building and development of the earth belong to you". So, man is responsible for the development of the earth [23], and every action that conflicts the environmental construction is forbidden.

D) Imam Ali (AS) writes in his famous letter to Malik Ashtar: "And your thought in the building of the earth (from which tribute is taken) should be greater than the thought of taking tribute" [24].

This letter implies that a prosperous, pleasant, and refreshing world can strengthen in man the motivation of providing the burden of the hereafter, for the more prosperous be the earth, the more it will be exploited and be provided for more burden. Therefore, every man is responsible for using and preserving the environment properly [25].

However, the Qur'an considers the destruction of the environment as a kind of corruption on the earth: "And make no mischief on the earth after it has been set in order" ('A'rāf: 85). In another verse, it says: "When he turns his back, His aim everywhere is to spread mischief through the earth and destroy crops and progeny. But Allah loveth not mischief' (Baqarah: 205). Therefore, observing the environmental balance and improving the land and its development are exemplified as Allah's covenant with man. Ignoring such a covenant causes loss: "But those who break the covenant of Allah, after having plighted their word thereto, and cut asunder those things which Allah has commanded to be joined, and work mischief in the land; on them is the curse; for them is the terrible home!" (Ra'd: 25)

Therefore, if man wants to perform his duty and accept the responsibility of Allah representative on earth, he must obey all divine commands, especially in developing, maintaining, and using the earth (environment). That is, the representative must abide by whom gave him a power of attorney, just like a divine trustee.

\subsubsection{Man is responsible for beings}

Responsibility is one of the good and pleasing attributes, and the Qur'an verses remind its importance for human beings. The Qur'an describes the action of "accepting responsibility" as "a heavy burden": "Nor can a bearer of burdens bear another's burdens" (Fātir: 18).

In this verse, "wizr" means heavy, and sometimes it also means responsibility. Allah warns that no one bears the heavy burden of responsibility but the man himself. On the Day of Judgment, everyone is responsible for his actions. This meaning greatly affects man's self-purification, i.e., whoever takes care of himself, never justifies his corruption and sins, putting him responsible to another one or society. He does not consider environmental pollution by others as a license for himself because everyone bears the burden of his guilt [23]. The dimensions of this responsibility are so vast that it includes human organs. Allah says in the Qur'an: "And pursue not that of which thou hast no knowledge; for surely the hearing, the sight, the heart, all of those shall be questioned of (on the day of reckoning)" ('Isrā': 36).

Responsibility is so important that in many interpretations "the divine trust" in verse: "We did indeed offer the trust to the heavens and the earth and the mountains; but they refused to undertake it, being afraid thereof: but man undertook it; he was indeed unjust and foolish" ('Ahzāb: 32), is described as the same commitment and acceptance of responsibility. The Qur'an introduces man as a being who is trustworthy to Allah because all beings 
in the universe except man did not accept it. This great trust was given to man because he had this ability.

Imam Ali (AS) instructed his followers to be pious for their assumed responsibilities. He holds them accountable even to the earth and the animals, saying: "Fear Allah for His servants and cities, for you are responsible even for the lands and animals. Obey Allah and avoid His disobedience" [26].

Allameh Mottaqi, under this tradition, writes: “Asking about lands means why you destroyed this one and built another, and why you did not worship Allah therein. In addition, asking about animals means why you left them hungry, hurt them, and missed their rights" [27].

Therefore, it is necessary to avoid wasting divine blessings, especially the environment, and causing harm. Allama Javadi Amoli says: "The purpose of human creation is producing good tempers. The caliph of Allah is defined by three responsibilities: worldview, world preservation, and world decoration" [28]. These three responsibilities make a person sensitive to protecting people's rights and the environment. On the other hand, based on this feeling, he also warns others of destroying the environment and informs them of their duty to protect and preserve the environment.

\subsubsection{Man is the servant of Allah on the earth}

The unique view of the Qur'an on nature is a divine sign: "And among His signs is the creation of the heavens and the earth, and the variations in your languages and your colors: verily in that are signs for those who know" (Rūm: 22). Although man is the caliph of Allah, he never has complete authority to use all the divine blessings in any way, which have been entrusted to him for a few days. Being a divine caliph can only continue if man remains a servant of Allah and does not betray the trust given to him: "I have only created Jinns and men, that they may serve Me" (Dhārīyāt: 56). Allah created man to be a servant to Him to be closer to Him. So, man should gain the pleasure of Allah and approach Him through servitude [29] because the purpose of human creation is worshiping based on knowledge.

Allah loves all His creatures. Accordingly, human beings should serve Him well and see all of Allah's creatures, including man, animals, plants, and nature, as respectful. They should respect their rights and observe and deal with them with the mercy and compassion that Allah wants. In such a case, they will perform their ba- sic tasks of expressing servitude and gratitude to divine blessings.

All commentators agree that the purpose of worship is to do what Allah has asked of a man. If man obeys the commands of his Allah and abstains from what Allah denies, i.e., all commands and forbiddances were taken from the Book and Sunnah, he will be a worthy worshiper and servant [30].

One of the examples of servitude is obedience, whose one of the elements is trustworthiness. A reliable example is the prevention of environmental degradation because the whole system of existence and man is under the lordship of Allah. In Islam, man is both "Abdullah" (servant of Allah- and so passive towards Allah) and the caliph of Allah (and so guardian towards this world). Therefore, the subjugation of nature in man's hands is limited to the divine laws, whereas a man who does not consider himself the servant of Allah and is not subject to the divine will be destructive to the environment and nature [31].

Therefore, man, by recognizing his servitude duties, will have a conscious attitude towards the environment. If a man sees the elements of nature as they are constantly creatures praising and worshiping Allah, he would have a conscious insight based on the correct cognition and understanding. Man can reach a level that hears beings' praise and then accompany them. So he treats these creatures respectfully and observes their rights. First of all, these rights include the protection and respect of their existence and their proper and wise use as divine resources and blessings in the hands of human beings.

The wise, thoughtful, and responsible devotee always observes justice while using natural resources and does not take steps to destroy the environment. Such a person is on the path of perfection towards Allah. He is the best model of practical ethics in enjoying the divine natural blessings.

\subsection{The origins of environmental degradation}

In the Qur'anic analysis, there is a close connection between human actions and natural events. Human behavior can lead to the growth and improvement of the living conditions of plants and animals or expose them to extinction.

The Holy Qur'an considers human insights and beliefs effective in improving or destroying the plant and animal environment: "If the people of the towns had but believed and feared Allah, We should indeed have opened out to them (all kinds of) blessings from heaven 
and earth; but they rejected (the truth), and We brought them to book for their misdeeds" ("A'rāf: 96).

This verse indicates that Allah orders man to avoid polytheism and sins so that He will open the doors of blessings and mercy from the sky due to the rain and from the earth due to the growth of plants and the production of fruits. In such a way that if a man acts based on nature and creation, Allah will be pleased with him, and divine blessings will be sent down to him. In contrast, whenever he goes against the laws of creation, the current virtuous and decorated system turns to corruption and ruins his life [27].

Although Allah created nature for man, "It is He who hath created for you all things that are on earth..." (Baqarah: 29). He mentions the factors that are inside a person, considered as the origins of environmental degradation. The basis of these roots is in human selfishness, passion, and lust. Some of these essential factors are as follows.

\subsubsection{Whims and vain desires}

According to the Qur'an, one of the greatest roots of destruction is whims and vain desires. The Qur'an condemns following whims, for it is one of the types of harmful adherence. For instance, in a verse, Allah Almighty avoids vain desires, using the verb "do not follow" (lā tattabi'): “....and follow not their vain desires, diverging from the truth..." (Mā'idah: 48). In another verse, He encourages those who do not follow vain desires: "And for such as had entertained the fear of standing before their Lord's (tribunal) and had restrained (their) soul from lower desires. Their abode will be the garden" (Nāzi’āt: 40-41) [32].

Imam Ali (AS) also says in this regard: "Impose moral virtues to your rebellious soul by hard effort and endurance, for natural human desire inclines to lust and moral vices" [33].

There are various instincts and desires in man, all of which are necessary for his survival, but sometimes they are manifested elegantly and get out of the form of an obedient tool in the hands of intellect. In such a case, they base rebellion, rule over the whole human being and take control of him. This is called "whim and vain desire", which is more dangerous than idolatry. No being is more dangerous and harmful than an unbelieving and rebellious fanatic who obeys whims. Accordingly, in verse Anfāl: 22, such a person is called "sharr al-dawāb" (the worst creatures) [34].
In another place, to reflect this fact, Allah says: "Seest thou such a one as taketh for his Allah his passion (or impulse)? Or thinkest thou that most of them listen or understand? They are only like cattle; nay, they are farther astray from the way" (Furqān: 43-44). These misleading selfish people who pursue their desires in the unprincipled exploitation of the environment and the divine blessings destroy the environment and produce complex environmental crises, similar to what the advanced and claimant world of civilization is facing today [27].

Allah has warned about this in several verses. Vain desires draw veils on the human intellect, adorns his bad deeds in his eyes, and deprives him of the ability of understanding, which is the greatest blessing of Allah and man's privilege over the animal, as Allah says: "Is then one who is on a clear (Path) from his Lord, no better than one to whom the evil of his conduct seems pleasing, and such as follow their lusts?" (Muhammad: 14) [23].

In addition, whims and lusts are the worst misguidances, as the Qur'an says: “.... and who is more astray than one who follows his lusts, devoid of guidance from Allah?..." (Qisas: 50). It is also an obstacle to justice and fairness, as the Qur'an says: "Follow not the lusts (of your hearts), lest ye swerve" (Nisā': 135).

Therefore, it is not difficult to distinguish truth from false, provided that man is not subject to his lusts. This false deity (idol) contaminates man with many sins, including the destruction of the environment. If we think well, we will be well aware of the depth of this statement because whim is the source of negligence and ignorance. It is referred to in the Qur'an that if the system of the heavens and the earth revolves around the whims and vain desires of the people, corruption will take over the entire universe: "If the truth had been in accord with their desires, truly the heavens and the earth, and all beings therein would have been in ruin! Nay, we have sent them their admonition, but they turn away from their admonition" (Mu'minūn: 71).

In short, where whim exists, neither the sign of religion nor intellect is involved. There is nothing but misery, suffering, calamity, cruelty, and corruption [23].

Reflecting on these verses, one may conclude that in many cases, for those who fail to understand the truth, whims were the reason behind it. Whim does not allow them to understand the truth. They may take actions such as environmental degradation. The elements that are more prevalent in selfishness and whims are as follows: 


\subsubsection{Greed and avarice}

Terminologically, "greed" means an intense desire for something [35], and "avarice" means the desire of the soul for something based on intense desire and greed [36]. In Qur'anic terminology, they refer to "the expectation and greed in people's property and life" (Baqarah: 96) [37].

In the Qur'an, these are among the unpleasant human traits: "Truly man was created very impatient" (Ma'ārij: 19); “Fretful when evil touches him” (Ma'ārij: 20); “And niggardly when good reaches him” (Ma'ārij: 21).

Some commentators and philologists interpreted the word "halū"" in the verse Ma'ārij: 19 as "greedy", and some interpreted it as "impatient". Allah has created instincts and attributes in the man who are potentially the means of perfection and happiness. When these attributes are misguided and abused, they will be led to misery, evil deeds, and corruption. For example, greed is a power that does not allow man to stop his efforts soon and be satisfied with only one blessing. Allameh Tabātabā'̄ says that the word "halū'" is the intensity of greed. He believes that greed is divided into divine greed, which is useful and desirable, and human greed, which is deviant and reprehensible. "These two words, namely greed and halü', are interpreted in the next two verses in which halū' is a person who is very impatient when dealing with adversity and when he achieves good, he refuses to give alms to others", he added.

So greed is not bad in itself. It becomes bad If a person performs it badly, does not channel it properly, and consumes it wherever it occurs, whether it is deserved or not. The carnal attribute of greed, if kept in moderation, is a virtue, and if it deviates to excess, it becomes vile and reprehensible. Man, at the beginning of his life, while he is a child, sees everything that is good or evil for him, and with those emotional instincts that he is equipped with, he recognizes his good and evil. $\mathrm{He}$ understands what he likes, and his inner forces whet its appetite, but without setting limits for it. When he faces pain or disgust, he starts suffering and whining, and when someone wants to disturb him, he prevents him in any possible way, even if he cries or shouts. This extreme greed for goodness is an attribute of perfection, which, if it were not, would not have sought for perfection, the attraction of good and repulsion of evil, as the Qur'an says: "And violent is he in his love of wealth" ('Ādīyāt: 8). And when he reaches maturity and growth, he is equipped with another system, namely the intellect, with which he understands the truth of things, recognizes the belief in truth and good deeds. Then the intense greed in his childhood turns into another greed, i.e., the intense greed for the true good and intense disgust of the punishment of the hereafter. Considering that the true good is competing towards Allah's forgiveness, and true evil is the disobedience of Allah Almighty, as a result, such a person does not get saturated by good deeds and does not intend to $\sin$. He is not greedy for worldly good and evil and does not exceed the divine limits. He controls his greed with the virtue of patience when dealing with $\sin$. He also controls his greed for obedience to the Lord in wealth and employment in the world with the virtue of patience, and so on. This greed would be the perfect virtue for such a person, the meaning said in the verses [38].

Therefore, the greed that is attributed to Allah is the greed for true good, and the greed that is spent on accumulating wealth and neglecting Allah is attributed to human beings. Man himself misuses divine greed and makes it into punishment. On the other hand, Allah has made the blessings of nature and the environment the bedrock of man's happiness and enjoyment of divine blessings so that he can desirably use them. If a person pollutes and destroys nature and the environment by his greedy exploitation, he disbelieves in the great blessing of nature and deserves the worldly punishment, deprived of this divine blessing, for all goods and virtues are due to Allah, and all evils belong to human action. Greed is, therefore, the result of suspicion of Allah, and its output is the intensification of this suspicion [39].

This meaning is also referred to in the decree of Malik Ashtar, in which Imam Ali (AS) warns Malik of consulting with miserly, cowardly, and greedy people, adding: "Stinginess, fear, and greed are different instincts with the same root, i.e., suspicion of Allah" [40].

Therefore, a person who has a good suspicion of Allah and His power to fulfill the promises (He has made about providing servants' sustenance) will never be greedy for accumulating wealth. Man thinks he can achieve his goal with greed, while if he trusts in Allah and believes in Him, he will know Allah is the best provider, as the Qur'an says: “And He provides for him from (sources) he never could imagine. And if anyone puts his trust in Allah, sufficient is (Allah) for him. For Allah will surely accomplish His purpose: verily, for all things has Allah appointed a due proportion" (Talāq: 3). Hence, he does not need to collect wealth greedily, for greed makes him encroach on the rights of others and nature. Imam Hussein (AS) says: "And if the daily breads are divided and destined, then less greed is more beautiful and if the end of collecting property is to leave them, then why a free man is greedy to such an abandoned thing" [41]. 
Moreover, earning wealth based on oppression and injustice to the environment is neither permanent nor stays with its owner forever. It may also cause deprivations such as getting out of Allah's mercy and blessings due to his inner qualities such as greed and neglecting divine traditions and covenants. Allah says: "Because Allah will never change the grace which He hath bestowed on people until they change what is in their (own) souls..." (Anfāl: 53).

If a man knows his actions in the environment will be manifested in the form of Hell or Heaven in the hereafter, he will be more sensitive to his acts concerning the environment and even to the ugly actions of those who have false beliefs and destroy the environment.

Therefore, one of the most important causes of environmental degradation is human misbehavior, i.e., his moral and internal crisis (greed) and his wrongdoing towards nature and other divine blessings.

\subsubsection{Arrogance}

The Arabic word kibr (arrogance) derives from the root k-b-r meaning great accompanied by a kind of hardship, i.e., considering oneself great $[42,43]$. Technically, it is referred to as a person who sees himself superior to another, and then such an action will be reflected in arrogant acts and behaviors $[44,45]$. Allah says: “...nor am I a pretender" (Sād: 86).

If you are not a pretender, you will live happily... If you are not a possessor, you will die happily.

Arrogance and selfishness are other causes of environmental degradation. Allah says: "When our signs are rehearsed to such a one, he turns away in arrogance as if he heard them not as if there were deafness in both his ears: announce to him a grievous chastisement" (Luqmān: 7); "He hears the signs of Allah rehearsed to him, yet is obstinate and lofty as if he had not heard them: then announce to him a chastisement grievous!" (Jāthīyah: 8).

Arrogance both hinders knowing the truth of existence and will lead to uncontrollable domination over the environment. Allah sees arrogance as an obstacle to knowing the truth and understanding affairs, as He says: "Those who behave arrogantly on the earth in defiance of right they will I turn away from My signs” ('A'rāf: 146).

A person seeking dominance over others and expects everything to be done according to his desire, how can he understand that everything prostrates to Allah, without any arrogance? "And to Allah doth prostrate all that is in the heavens and on earth, whether moving creatures or the angels: for none are arrogant (before their Lord)" (Nahl: 49).

Therefore, the Qur'an guides human beings to a way that meets their needs from the divine nature and blessings, and observes the rights of all components of nature and the environment and all active components in the natural ecosystem. As a result, these components enjoy their right to live and play an influential role in preventing environmental degradation.

\subsubsection{Extravagance}

The Arabic word "Isrāf" (extravagance) means to be excessive, to exceed the limit of moderation [46], to be ignorant, and to give charity neither for the sake of Allah nor towards His obedience [42].

According to the Holy Qur'an, extravagance in natural resources, which meet a huge part of human needs, is unjust and causes the wrath of Allah Almighty: "It is He who produceth gardens, with trellises and without, and dates, and tilth with the production of all kinds, and olives and pomegranates, similar (in kind) and different (in variety): eat of their fruit in their season, but render the dues that are proper on the day that the harvest is gathered. But waste not by excess: for Allah loveth not the wasters" ('An'ām: 141).

According to this verse, Allah Almighty bestowed the trees and their fruits with divine gifts and blessings to the ground as one of the most important blessings and valuable natural assets on earth. Allah Almighty has provided us with plants and trees or forests and pastures that have vital functions in human life [47]. As a result, extravagance in consumption and actions that cause contamination and destruction of essential elements of the environment contradicts the Islamic teachings and harm the real interests of human beings [48].

Islam does not accept any excuse for polluting nature, even against the enemy. It is narrated from Imam Sadeq (AS) that "Do not pollute the water of the people". Imam Ali (AS) also says: "The Messenger of Allah (PBUH) forbade pouring poison in the land of the polytheists" [49]. These narrations indicate Islam's emphasis and support for the environment. In some narrations also life without clean air, abundant and refreshing water, fertile and cultivable land are regarded as a miserable life [41].

These verses and narrations show that it is necessary to preserve the environment and avoid extravagance. It 
then provides healthy conditions for humans to enjoy health and make optimal use of the divine blessings.

In addition to narrations that rely on environmental protection, there are also those in which environmental degradation is forbidden; As it is narrated from the Holy Prophet (PBUH): "Do not cut down trees because Allah will punish you" [22].

The Holy Quran, in some of its teachings, presents commands and forbiddances together. It orders men to benefit from the product of nature and forbids imbalance in its consumption, by which the Allah kindness would be lost: ". . .eat and drink: but waste not by excess, for Allah loveth not the wasters" ("A'rāf: 31); “....and the transgressors will be companions of the fire!” (Mu'min: 43). These verses may imply the mandatory and legal rules of the sanctity of nature destruction and man's misuse of it, and the need to preserve the environment [50].

Therefore, according to the Qur'an, man has the right to enjoy a healthy environment. This right has some duties, including that he must recognize the rights of others and refrain from doing actions that deprive others of a healthy environment. The Iranian supreme leader says in this regard: "The supreme goal of Islam is to provide all generations with divine blessings, to keep a healthy society away from the social gap, that would be capable for growth and prosperity, and to bring the religious requirements to maintain balance and in the use of natural gifts, through avoiding extravagance and oblige not to harm others" [51].

In addition, one way to prevent extravagance, greed, arrogance, and whims is to believe that the right to enjoy the environment belongs to everyone and is not exclusive to one human.

\subsubsection{Satanic temptations}

Sometimes man commits behaviors that lead to environmental degradation and are rooted in human ignorance and negligence. Satan reinforces these misconducts in humans.

According to the Qur'an, Allah allows Satan to tempt the children of Adam. In response, Satan who has announced that he would deceive the children of Adam, Allah says: "And arose those whom thou canst among them, with thy (seductive) voice; make assaults on them with thy cavalry and thy infantry; mutually share with them wealth and children, and make promises to them. But Satan promises them nothing but deceit" ('Isrā': 64).
Therefore, another cause of environmental degradation may be considered Satanic temptations, and man should be warned about it and be careful of his deeds. Because the Qur'an quotes from Satan that in the Day of Judgment, in response to those who say that Satan is the responsible for their astray, will say: "...I had no authority over you except to call you, but ye listened to me: then reproach not me, but reproach your own souls..." (Ibrahim: 22).

When the Holy Qur'an says that Allah has subjugated nature to man, it does not mean ordinary domination over nature, but it means overcoming what man is allowed to do only if it is following the divine laws. If man deviates from his path, he will do anything due to his authority and position. Such a creature is capable of destructive power, just like Satan. These humanoids, at least for a short time, have Allah like and destructive dominions [30].

Satan plays his role here through commanding to obscene acts and threatening with poverty, as Allah says: "The Satan threatens you with poverty and bids you to conduct unseemly. Allah promiseth you His forgiveness and bounties. And Allah careth for all and He knoweth all things" (Baqarah: 268). This misbelief causes man's greed to be increased, and consequently, he destroys the environment. Another Satan's role here is an adornment, meaning that he makes the sin of man beautiful in his eyes, as it is stated in Nahj al-Balaghah: Sermon 64: "Satan is always with man and adorns his sins so that he may dominate him" [52].

Many people know that environmental degradation is a sin and deprives others of their rights. However, they still commit it because Satan adorns their actions so that they do not dislike their behavior. So Satan plays his role in environmental degradation. Man must realize that he should not fall into selfishness, greed, etc., and then destroy the environment based on the temptations of Satan. Since man does not see himself as independent, he should not allow himself to destroy his own environment by following Satanic temptations.

The Qur'an provides three solutions to escape from Satanic temptations [53]:

1) Man should consider Satan as the enemy: "Satan is an obvious enemy to man" ('Isrā': 53). He should neither be influenced by Satan nor do deeds contrary to the principle of humanity. So, "Satan is your enemy, so take him as your enemy" (Fātir: 6). 
2) Man should seek refuge in Allah against the evil of Satan: "If a suggestion from Satan assails thy (mind), seek refuge with Allah; for He heareth and knoweth (all things)".

3) Man should act sincerely; this advice has been repeated in the Qur'an twice: “(Iblis) said: 'O my Lord! because Thou hast put me in the wrong, I will make (wrong) fair-seeming to them on the earth, and I will put them all in the wrong; except Thy chosen servants among them"' (Hijr: 39-40).

\subsection{Opinions and ideas of the research team}

Today, due to industrialization and the complexity of social life, humans have inadvertently manipulated nature. Unfortunately, local, indigenous, national, and international guidelines and protocols, even with a relative agreement, have not prevented human encroachment on nature. Therefore, one of our solutions is to use the social sciences and humanities, especially the innate dough of revelatory teachings for self-preservation and human control for the undesirable use of the environment. Because some people have a particular interest in religious teachings, researchers and experts have paid attention to this issue in our country for several years. Some acceptable principles are as follows:

- Using verses and hadiths about bioethics, lifestyle, and the philosophy of creation,

- Using religious teachings to conquer and develop nature in a way that is compatible with nature and not its destruction,

- Using different jurisprudential rules in this regard is very helpful and instructive,

- Using all local, indigenous, national, and international guidelines and protocols based on accountability and social responsibility of citizens,

- Using the codes of environmental ethics,

- Using the teachings of humanities in health to explain and determine accreditation indicators to promote health and preserve the environment.

\section{Conclusion}

Allah provided nature and the world with all the facilities and resources available to human beings. He asked humans to possess it intellectually and use it for their own survival.
The human servitude, as the caliph and representative of the prosperity and the chosen trustee of Allah on earth, requires obeying the commands of Allah and constructing the environment, for he is responsible before Allah Almighty and will be asked on the Day of Judgment. Those who are entitled to these good qualities always go on maintaining the successorship position through environmental protection, the task of land development against its destruction, preserving the environment as a divine trust, and the responsibility to protect others and the environment's rights. They are Allah's servants and are thankful for the divine blessings and will be rewarded by Allah as faithful servants.

According to the Qur'an, the environmental destructive factors such as greed, arrogance, selfishness, whims, vain desires, and Satanic temptations originate from some internal and external dimensions of human personality and are incompatible with man's nature. They are only controlled and eliminated by man's knowledge of himself, relying on Allah and following the instructions of the Qur'an. In this condition, everyone will enjoy a healthy and pleasant environment.

\section{Ethical Considerations}

\section{Compliance with ethical guidelines}

There were no ethical considerations to be considered in this research.

\section{Funding}

The paper was extracted from the MSc. Thesis or extracted from a research project of the second author, Department of Hadith and Qur'anic Sciences, Faculty of Theology, Campus of Qom, University of Tehran.

\section{Author's contributions}

All authors equally contributed to preparing this article.

\section{Conflict of interest}

The authors declared no conflict of interest.

\section{Acknowledgements}

The authors Want to Thank the Faculty of Theology (Sciences of Qur'an and Hadith) of the University of Tehran (Campus of Qom) and the Cooperation Department of Environmental Health Engineering of Baqiyatallah University of Medical Sciences for completing the research project. 


\section{References}

[1] Masoumbeigi H, Mahmoudi N, Sepandi M, ghanizade Gh [Survey of environmental health status of the selected military centers, 2013 (Persian)]. J Police Med. 2016; 5(2):111-22. http://jpmed.ir/article-1-428-en.html

[2] Salvato JA, Nemerow NL, Agardy FJ. Environmental engineering. New Jersey: John Wiley \& Sons; 2003. http:// medical.rums.ac.ir/uploads/rums_environmental_engineering_salvato.pdf

[3] Haddadi M. Fundamentals of environmental protection in Islam. J Inform Wisdom Knowledge. 2009; 3(12):54-57. https://www.magiran.com/paper/606693

[4] Papan-Matin F. The constitution of the Islamic Republic of Iran. Iran Stud. 2014; 47(1):159-200. [DOI:10.1080/00210862.2 013.825505]

[5] Lundie S, Peters GM. Life cycle assessment of food waste management options. J Clean Prod. 2005; 13(3):275-86. [DOI:10.1016/j.jclepro.2004.02.020]

[6] Masoumbeigi H, Safavi SA, Yousefi khoraem M, Mahmoudi $\mathrm{N}$. Survey of solid waste management status in academic centers: Case study in a military university. Int J Ayurvedic Med. 2018; 9(2):99-105. https:// www.ijam.co.in/index.php/ ijam/article/view/1080

[7] Lorenzetti E, Carvalho JC, Carvalho LC, Martins CC, Goncalves AC, Tartaro J, et al. Environmental impact of toxic metals on water and soil by agrochemicals, emerging pollutants and remediation methods. Aust J Crop Sci. 2019; 13(09):15205. [DOI:10.21475/ajcs.19.13.09.p1788]

[8] Kumar M, Borah P, Devi P. Chapter 3 - Priority and emerging pollutants in water. In: Devi P, Singh $P$, Kansal SK, editors Inorganic pollutants in water. Amsterdam: Elsevier; 2020. p. 33-49. [DOI:10.1016/B978-0-12-818965-8.00003-2]

[9] Durán-Álvarez JC, Sánchez Y, Prado B, Jiménez B. The transport of three emerging pollutants through an agricultural soil irrigated with untreated wastewater. J Water Reuse Desalination. 2014; 4(1):9-17. [DOI:10.2166/wrd.2013.003]

[10] Manisalidis I, Stavropoulou E, Stavropoulos A, Bezirtzoglou E. Environmental and health impacts of air pollution: A review. Front Public Health. 2020; 8:14. [DOI:10.3389/ fpubh.2020.00014] [PMID] [PMCID]

[11] Mahmoudi N, Latifi AM, Amani MA, Masoumbeigi H, Ghanizadeh G. Data on the environmental exposure to lead in Iran. Data Brief. 2018; 20:1133-41. [PMID] [PMCID]

[12] Jonidi Jafari A, Esrafili A, Moradi Y, Mahmoudi N. Mercury level in biological samples of dentists in Iran: A systematic review and meta-analysis. J Environ Health Sci Eng. 2020; 18(2):1655-69. [DOI:10.1007/s40201-020-00558-w] [PMID] [PMCID]

[13] Mahmoudi N, Jonidi Jafari A, Moradi Y, Esrafili A. The mercury level in hair and breast milk of lactating mothers in Iran: A systematic review and meta-analysis. J Environ Health Sci Eng. 2020; 18(1):355-66. [DOI:10.1007/s40201-02000460-5] [PMID] [PMCID]

[14] Muharramnejad N, Imran H. Planning a management model for the sustainable development of teaching the environment for the young generation of the country. J Environ Sci Technol. 2006; 8(1):68-77. https:/ /jest.srbiau.ac.ir/article_350.html?lang=fa
[15] Gorji A. [Islam and the environment (Persian)] J Noor- Elm. 1984; 4:111-6. http://ensani.ir/fa/ article/66648/\%D8\%A7\%D8\%

[16] Saed N, Tila P. [Collection of laws and regulations for environmental protection of Iran (Persian)]. Tehran: Khorsandi Publications; 2013. http://opac.nlai.ir/opacprod/search/briefListSearch.do?command=FULL_VIE W\&id=1132230\&pageStatus=1\&sortKeyValue1=sortkey_ title\&sortKeyValue2=sortkey_author

[17] Fazlan Kh. [Islam and the environment (Persian)]. Mashhad: Astan Quds Razavi Publication, Behnashar; 1999. http:/ / opac.nlai.ir/opac-prod/search/briefListSearch. do? command=FULL_VIEW\&id=586259\&pageStatus $=1 \&$ so rtKeyValue1=sortkey_title\&sortKeyValue2=sortkey_author

[18] Kulayni M. Usul al-Kafi (Chapter on Wisdom and Ignorance, Narration one) (Vol. 1). 3rd ed. Qom: Osweh Publications; 1996: 10.

[19] Hosseini SA. Nature, Allah creature. Journal of Jihad Culture. 2001; 6(24):146. http://ensani.ir/fa/article/ journal/779/\%D9\%81

[20] Motahari M. [Introduction to the Islamic worldview (Persian)]. Qom: Sadra Publishing; 2005. http://opac.nlai.ir/ opac-prod/search/briefListSearch.do?command=

[21] Javadi-Amoli A. [Islam and the environment (Persian)]. Qom: Esra Publishings; 2007. http://opac.nlai.ir/opac-prod/ search/briefListSearch.do?

[22] Hurr-Āmilī M. Wasā'il al-Shī'ah (vol. 13). $7^{\text {th }}$ ed. Tehran Maktabat al-Islāmīyah; 2008. https://www.gisoom.com/ book/1479777/

[23] Makarem-Shirazi N. [Tafsir nemuneh (Persian)]. Tehran: Dar al-Kutub al-Islamiyyah; 2008. http://opac.nlai.ir/opacprod/search/briefListSearch.do?command

[24] Faiz al-Islam AN. [Translation and description of nahi albalaghah (Persian)]. Tehran: Institute of Publishing Faiz alIslam; 2000. https://lib.eshia.ir/11479/1/4

[25] Shafiee-Mazandarani, SM. The motivation of attention to the environment from the perspective of the qur'an and sunnah. Articles collection of national conference of the qur'an and natural sciences. Mashhad: Islamic Azad University, the Quranic Research Foundation of the Seminary and the University; 2007. https://www.gisoom.com/book/1417931/C/

[26] Seyyed-Razi M. Nahj al-Balaghah. Translated by: Hossein A. Tehran: Payam Azadi Publications; 2012. https://www. gisoom.com/book/1884053//

[27] Mottaqi T. [Environmental ethics of the Holy Prophet (PBUH) (Persian)]. Qom: Islamic Research Broadcasting Center; 2007. http://opac.nlai.ir/opac-prod/search/briefListSearch.do?command=

[28] Javadi-Amoli A. [The only way to cure the world situation is to follow morality and faith (Persian)]. J Ofogh-e Hawzeh. 2010; 299(20):3. https://hawzah.net/ar/Magazine/View/64 35/7824/100446/\%D8\%AA\%D9\%86\%D9\%87\%D8\%A7-

[29] Golshani M. Qur'an and natural sciences. Tehran: Motahar Publications; 2002. https://www.gisoom.com/ book/11053996/\%8\%AA/ 
[30] Pourmohammadi A, Mohaghegh-Damad M. [Philosophical foundations of bioethics (Persian)]. Tehran: Hoghooghi Publications; 2008. http://opac.nlai.ir/opac-prod/search/ briefListSearch.do?command=FULL=sortkey_author

[31] Nasr SH. [The need for sacred science (Persian)]. Qom: Taha Cultural Institute; 2000. http:/ / opac.nlai.ir/opac-prod/ search/briefListSearch.do?_author

[32] Khorramshahi B. The encyclopedia of the Qur'an and qur'anic studies .Tehran: Dustan Publications; 2014. https:// www.gisoom.com/book/11094223/D8\%AF-2/

[33] Muhaddith-Nuri MH.[Mustadrak al-Wasā'il wa Mustanbat al-Masā'il (Persian)]. Qom: Tabasi Haeri Library; 1899. http://opac.nlai.ir/opac-prod/search/briefListSearch. do?command=_author

[34] Khodajouian F. [The position of the environment in Islam and christianity (The bible and its interpretations) (Persian)] [PhDdissertation].Tehran:University of Tehran;2005.https:/ / alefbalib.com/Metadata/152385/\%D8\%AC\%D8\%\%86)

[35] Mostafavi H. [Al-Tahqīq fì Kalimāt al-Qur'an (Persian)] Tehran: Book Translation and Publishing Company; 1981. http://opac.nlai.ir/opac-prod/search/briefListSearch. do? command=_author

[36] Ragheb-Isfahani H. [Al-mufradat fi gharib al-Qur'an (Persin)]. Tehran/; The Aghigh Book; 2015. http://opac.nlai.ir/ opac-prod/search/briefListSearch.do?command_author

[37] Allameh-Tabātabā'î SMH. [Tafsir al-mīzān (Persian)] Qom: The Islamic Publishing Office of the Teachers Society of the Seminary of Qom; 1981. http://opac.nlai.ir/opac-prod/ search/briefListSearch.do?command=Value2=

[38] Allameh-Tabātabā'î SMH. Tafsir al-mīzān(Vol. 20). $5^{\text {th }}$ ed. Translated by: Mousavi-Hamedani, SMB. Qom: The Islamic Publishing Office of the Teachers Society of the Seminary of Qom; 1995: 18-20. https:/ /alefbalib.com/index.aspx?pid=14\& $\mathrm{GID}=205400 \& \mathrm{ID}=244700$

[39] Makarem-Shirazi, N. [Ethics in the Quran (Persian)]. Tehran Rudaki Center for the Rehabilitation of the Blind; 2011. http:// opac.nlai.ir/opac-prod/search/briefListSearch.do?author

[40] Saleh S. [Nahj al-Balaghah (Persian)]. Tehran: Islamic; 1991. http://opac.nlai.ir/opac-prod/search/briefListSearch do?command=author

[41] Majlisi MB. Bihar al-Anwar (Vol. 44). $3^{\text {rd }}$ ed. Beirut, Lebanon: Dar Al-Ihyā'Al-Turāth Al-Arabī; 1984: 374 https:/ / www.ghbook.ir/index.php?option=com dbook\&task=viewbook\&book_id=1000939044\&lang=fa

[42] Ibn-Manzur JM. [Lisān al-Arab (Arabic)]. Beirut: Darsader Publications; 1996. http://opac.nlai.ir/opac-prod/search/ briefListSearch.do?_author

[43] Qurashi SAA. Qur'an dictionary (The word kibr). Dar alKutub al-Islamiyah; 1992. https:/ /lib.eshia.ir/71428/4/0

[44] Faiz Kashani MH, Shah Morteza M. [Al-Mahajat AlBayza (Arabic)]. Qom: Islamic Publications House; 1960 http:/ / opac.nlai.ir/opac-prod/search/briefListSearch. do?command=_author

[45] Naraqi MA. [Mi'rāj al-Sa'ādah (Persian)]. Qom: Hijrat Publications; 1998. http:// sarbazaneislam.com/ketab-islammerajosaadah.pdf
[46] Tayyeb Hosseini SM. Qur'an Culture and Teachings Center: Encyclopedia of the Holy Qur'an (Vol. 3). 2nd ed. Qom: Būstān-e Ketab; 2007: 200. http://www.maarefquran.com/ $\mathrm{fa} /$ Book/Detail/160/\%85\#

[47] Hosseini SA. [Nature in alawite biography (Persian)]. Qom: Khakian Publications; 2010. http://fipak.areeo.ac.ir/ site/catalogue/18484777

[48] Environmental Protection Organization. [Environment from the perspective of Islam. The Collected articles of the Islam and the environment conference (Persian)]. Tehran: Environmental Protection Organization; 2008. http:/ / opac.nlai. ir/opac-prod/search/briefListSearch.do?command=_author

[49] Haghshenas M, Zakeri MH. [Searching for environmental ethical concepts in Islamic teachings (Persian)]. Ethics Sci Technol. 2008; 3(1\&2):23-30. https://www.sid.ir/en/journal/ViewPaper.aspx?ID=172467

[50] Naghibi A. [Environment and its rights from the perspective of the Holy Qur'an (Persian)] [Internet]. 2010 [updated 2021 September 10]. Available from: https://www. mehrnews.com/news/1136187.

[51] Bahrampour A, Samiei A. Environmental Law and the Judiciary. Articles Collection of the First Environmental Law Conference of Iran; 2003 June 12; Tehran, Iran: Barge Zaitone; 2004. https://www.gisoom.com/book/1292990/AF-1382/

[52] Imam Ali Ibn Abi Talib. Nahj al-Balaghah. 55 ${ }^{\text {th }}$ ed. Translated by: Mohammad Dashti, Qom: Cultural Research Institute of Amir al-Mo'menīn (AS); 2004. Sermon 64: 81. https:/ www.gisoom.com/book/1643624/\%8C/

[53] Abd al-Bāqī MF, Othman Taha. Al-Mu'jam al-Mufahras li Kalimāt al-Qur'an al-Karīm. Qom: Navid-e Islam Publications; 2004. https://www.gisoom.com/book/1294687/ 